\title{
ASAS-ASAS PENDIDIKAN ISLAM
}

\author{
Fatkhul Mubin \\ Fatkhulmubin90gmail.com
}

\section{A. PENDAHULUAN}

Asas pendidikan merupakan sesuatu kebenaran yang menjadi dasar atau tumpuan berpikir, baik pada tahap perancangan maupun pelaksanaan pendidikan. Khusus di Indonesia, terdapat beberapa asas pendidikan yang memberi arah dalam merancang dan melaksanakan pendidikan itu. Asas-asas tersebut bersumber baik dari kecenderungan umum pendidikan didunia maupun yang bersumber baik dari pemikiran dan pengalaman sepanjang sejarah upaya pendidikan di Indonesia.

Pendidikan itu mempunyai asas-asas tempat ia tegak dalam materi, interaksi, inovasi dan cita-citanya.Jadi ia seperti kedokteran, misalnya seperti tehnik atau pertanian.Masing-masing tidak dapat berdiri sendiri, tetapi merupakan suatu arena dimana di praktekan sejumlah ilmu yang erat hubungan satu sama lain dan jalin-menjalin. Bidang pertanian, misalnya merupakan tempat pertemuan kimia umum, kimia tanah, ilmu tumbuh-tumbuhan atau botani , lapisan bumi dan ilmu tanah, anatomi tumbuh-tumbuhan, klimatologi, genetic, pemakaman dan lainlain.Begitu juga berpuluh-puluh ilmu lain, hasil-hasil terapannya bertemu pada bidang pertanian. ${ }^{1}$

\footnotetext{
${ }^{1}$ Saihu, S. (2019). RINTISAN PERADABAN PROFETIK UMAT MANUSIA MELALUI PERISTIWA TURUNNYA ADAM AS KE-DUNIA. Mumtaz: Jurnal Studi Al-Quran dan Keislaman, 3(2), 268-279,

Saihu, S. (2019). Pendidikan Pluralisme Agama: Kajian tentang Integrasi Budaya dan Agama dalam Menyelesaikan Konflik Sosial Kontemporer. Jurnal Indo-Islamika, 9(1), 6790,

Saihu, S. (2019). IMPLEMENTASI MANAJEMEN BALANCED SCORECARD DI PONDOK PESANTREN JAM'IYYAH ISLAMIYYAH TANGERANG SELATAN. Mumtaz: Jurnal Studi Al-Quran dan Keislaman, 3(1), 1-22.

Saihu, S. (2019). KOMUNIKASI PENDIDIK TERHADAP ANAK BERKEBUTUHAN KHUSUS DI SEKOLAH KHUSUS ASY-SYIFA LARANGAN. Andragogi: Jurnal Pendidikan Islam dan Manajemen Pendidikan Islam, 1(3), 418-440.

Saihu, S., \& Marsiti, M. (2019). PENDIDIKAN KARAKTER DALAM UPAYA MENANGKAL RADIKALISME DI SMA NEGERI 3 KOTA DEPOK, JAWA BARAT. Andragogi: Jurnal Pendidikan Islam dan Manajemen Pendidikan Islam, 1(1), 2354.

Saihu, S. (2019). KONSEP MANUSIA DAN IMPLEMENTASINYA DALAM PERUMUSAN TUJUAN PENDIDIKAN ISLAM MENURUT MURTADHA MUTHAHHARI. Andragogi: Jurnal Pendidikan Islam dan Manajemen Pendidikan Islam, 1(2), 197-217.
} 
Jadi seorang dokter atau insinyur pertanian atau seorang pendidik memerlukan asas-asas untuk mempermahir profesi dan menambah pengetahuan, memperkarya pengalaman dan mengembangkan keterampilan. Ini menghendaki kita supaya jangan mengkajinya hanya sekali saja atau hanya untuk mendapatkan ijazah tetapi perlu selalu menela'ah dan terus berkomunikasi.

Jadi mengetahui dan mendalami asas-asas ini bukanlah tugas pemikir dan ahli-ahli saja, tetapi praktisioner di rumah sakit dan pabrik, kebun atau di sekolah. Berkenaan dengan asas-asas yang kita maksudkan, yaitu asas-asas pendidikan, dapat kita uraiakan dalam beberapa asas yang akan kita bahas pada makalah ini.

\section{B. PEMBAHASAN}

\section{Pengertian Asas-Asas Pendikan}

Asas pendidikan Islam adalah asas perkembangan dan pertumbuhan dalam perikehidupan yang berkeseimbangan antara kehidupan duniawiah dan ukhrawiah, jasmaniah dan rohaniah atau antara kehidupan materiil dan mental spiritual. Asasasas yang lain dalam pelaksanaan operasional seperti asas adil dan merata, asas menyeluruh dan asas integralitas, adalah juga dijadikan pegangan dalam pendidikan praktis sesuai pandangan teoritis yang dipegangi. ${ }^{2}$

Dalam Kamus Umum Bahasa Indonesia, kata asas bermakna suatu kebenaran yang menjadi pokok dasar atau tumpuan berfikir (berpendapat). ${ }^{3}$ Disebutkan pula terdapat kosa kata prinsip semakna dengan kata asas, jadi dapat dikatakan bahwa asas sama dengan prinsip. Dengan demikian yang dimaksud dengan asas pendidikan Islam adalah prinsip pendidikan Islam yaitu, kebenaran yang dijadikan pokok dasar dalam merumuskan dan melaksanakan pendidikan Islam. ${ }^{4}$

\footnotetext{
2 Nur Uhbiyati, Ilmu Pendidikan Islam. Bandung: CV Pustaka Setia. 1999. 18

${ }^{3}$ W.J.S, Purwadarminta. Kamus umum Bahasa Indonesia, Jakarta: Balai Pustaka. 2001. 63

${ }^{4}$ Saihu, S., \& Rohman, B. (2019). PEMBENTUKAN KARAKTER MELALUI MODEL PENDIDIKAN TRANSFROMATIFE LEARNING PADA SANTRI DI PONDOK PESANTREN NURUL IKHLAS BALI. Edukasi Islami: Jurnal Pendidikan Islam, 8(02), 435-452.

Saihu, S., \& Taufik, T. (2019). PERLINDUNGAN HUKUM BAGI GURU. Al Amin: Jurnal Kajian Ilmu dan Budaya Islam, 2(2), 105-116.

Saihu, S. (2020). KONSEP PEMBAHARUAN PENDIDIKAN ISLAM MENURUT FAZLURRAHMAN. Andragogi: Jurnal Pendidikan Islam dan Manajemen Pendidikan Islam, 2(1), 82-95.
} 
Prinsip-prinsip ajaran ini digunakan dalam merumuskan dan melaksanakan ajaran Islam. Prinsip-prinsip ini sifatnya permanen karena merupakan suatu ajaran dan tidak boleh dihilangkan atau diubah karena ketika prinsip tersebut dihilangkan atau diubah maka menghilangkan sifat dan karakter pendidikan Islam. ${ }^{5}$

\section{A. Asas-Asas Pokok Pendidikan}

Asas pendidikan merupakan sesuatu kebenaran yang menjadi dasar atau tumpuan berpikir, baik pada tahap perancangan maupun pelaksanaan pendidikan. Khusus untuk pendidikan di Indonesia, terdapat sejumlah asas yang memberi arah dalam merancang dan melaksanakan pendidikan itu. Asas-asas tersebut bersumber baik dari kecenderungan umum pendidikan didunia maupun yang bersumber baik dari pemikiran dan pengalaman sepanjang sejarah upaya pendidikan di Indonesia. Diantara berbagai asas tersebut, tiga buah asas akan dikaji lebih lanjut dalam paparan ini.

\section{Asas Tut Wuri Handayani}

Asas tutwuri handayani, yang kini menjadi semboyan Depdikbud, pada awalnya merupakan salah satu dari "Asas 1922" yakni tujuh buah asas dari

Saihu, S. (2020). ETIKA MENUNTUT ILMU MENURUT KITAB TA'LIM MUTA'ALIM. Al Amin: Jurnal Kajian Ilmu dan Budaya Islam, 3(1), 99-112.

Saihu, Aziz, A., Mubin, F., \& Sarnoto, A. Z. (2020). Design of islamic education based on local wisdom (An analysis of social learning theories in forming character through ngejot tradition in bali). International Journal of Advanced Science and Technology, 29(6), 12781293.

Ronaldo, R., Zulfikar, A., Saihu, Ismail, \& Wekke, I. S. (2020). International relations of the asia pacific in the age of trump. Journal of Environmental Treatment Techniques, 8(1), 244-246.

Saihu, M. M., \& Aziz, A. (2020). Implementasi Metode Pendidikan Pluralisme Dalam Mata Pelajaran Pendidikan Agama Islam. Belajea; Jurnal Pendidikan Islam, 5(1), 131-150.

Saihu, M. (2019). Urgensi 'Urf dalam Tradisi Male dan Relevansinya dalam Dakwah Islam di Jembrana-Bali. Jurnal Bimas Islam, 12(1), 173-201.

Saihu, S. (2020). The Effect of Using Talking Stick Learning Model on Student Learning Outcomes in Islamic Primary School of Jamiatul Khair, Ciledug Tangerang. Tarbawi: Jurnal Keilmuan Manajemen Pendidikan, 6(01), 61-68.

Saihu, S. (2020). Pendidikan sosial yang terkandung dalam Surat At-Taubah Ayat 71-

72. Edukasi Islami: Jurnal Pendidikan Islam, 9(01), 127-148.

5 Abudin Nata. Ilmu Pendidikan Islam. Jakarta : Kencana Prenada Media Grop. 2012. 102 
perguruan nasional taman siswa (didirikan 3 juli 1922). ${ }^{6}$ Sebagai asas pertama, tut wuri handayani merupakan inti dari sistem among dari perguruan itu. Asas maupun semboyan tutwuri handayaniyang dikumandangkan oleh kihajar dewanatara itu mendapat tanggapan positif dari Drs. R.m.p sustra kartono (filsafat dan ahli bahsa), yakni ketiga semboyan tersebut telah menyatu menjadi satu kesatuan asas, yakni:

1. Ing Ngrasa Sung Tulada (jika didepan, menjadi contoh)

2. Ing Madya Mangun Karsa (jika ditengah-tengah, membangkitkan kehendak, hasrat adalah motivasi)

3. Tut Wuri Handayani (jika dibelakang, mengikut dengan asas)

Dari sisi lain, pendidik setiap saat siap memberi uluran tangan apabila diperlukan anak, ing ngarsa ing tulodo (didepan memmberi contoh) adalah hal yang baik melihat kebutuhan anak maupun pertimbangan guru. Ing madya mangun karsa (ditengah membangkitkan kehendak) diterapkan dalam situasi kurang bergairah adalah ragu-ragu untuk mengambil keputusan atau tindakan, sehingga perlu di upayakan untuk motivasi, ketiga semboyan tersebut sebagi satu kesatuan asas (ing ngarsa sung tulada, ing madya mangun karsa, dan tut wuri handayani) telah menjadi asas penting dalm pendidikan di indonesia.

\footnotetext{
${ }^{6}$ Aziz, A., \& Saihu, S. (2019). Interpretasi Humanistik Kebahasaan: Upaya Kontekstualisasi Kaidah Bahasa Arab. Arabiyatuna: Jurnal Bahasa Arab, 3(2), 299-214

Saihu, S. (2019). PENDIDIKAN KARAKTER BERBASIS KEARIFAN LOKAL (STUDI DI JEMBRANA BALI). Edukasi Islami: Jurnal Pendidikan Islam, 8(01), 69-90.

Şahin, C. RELIGIA.

Saihu, S., \& Mailana, A. (2019). Teori pendidikan behavioristik pembentukan karakter masyarakat muslim dalam tradisi Ngejot di Bali. Ta'dibuna: Jurnal Pendidikan Islam, 8(2), 163-176.

Mubin, F. KEADILAN DALAM GENDER: KAJIAN KEPEMIMPINAN WANITA DALAM ISLAM1,

Saihu, M. (2019). Merawat Pluralisme Merawat Indonesia (Potret Pendidikan Pluralisme Agama Di Jembrana-Bali). Deepublish.

Mubin, F. (2019). TAFSIR EMANSIPATORIS: PEMBUMIAN METODOLOGI TAFSIR PEMBEBASAN. Mumtaz: Jurnal Studi Al-Quran dan Keislaman, 3(1), 131-151.

Mubin, F. MODEL-MODEL PEMBELAJARAN BERBASIS MADRASAH DAN KEGIATAN LAIN YANG DIPERLUKAN DI DALAMNYA (FAKTOR PENDUKUNGNYA).
} 


\section{Asas Belajar Sepanjang Hayat.}

Asas belajar sepanjang hayat (life long learning) merupakan sudut pandang dari sisi lain terhadap pendidikan seumur hidup (life long education). Pendidikan seumur hidup merupakan concep. Oleh karena itu,UNESCO Institute for education (UIE Hamburg) menetapkan suatu devinisi kerja yakni pendidikan seumur hidup adalah pendidikan yang harus meliputi:

1. Meliputi seluruh hidup setiap individu.

2. Mengarah kepada pembentukan, pembaharuan, peningkatan, dan sikap yang dapat meningkatkan kondisi hidupnya.

3. Tujuan akhirnya adalah mengembangkan penyadaran diri setiap individu.

\section{Asas Kemandirian dalam Belajar}

Perwujudan asas kemandirian dalam belajar akan mendapatkan guru dalam peran utama sebagai fasilitator dan motivator, di samping peran-peran yang lain : Informasi, organisasai dan lain-lain.

\section{B. Macam-Macam Asas-Asas Pendikan}

\section{Asas Sejarah ( Historis )}

Faktor sejarah dianggap sebagai salah satu faktor budaya yang paling penting yang mempengaruhi filsafat pendidikan, misalnya kepribadian nasional yang menjadi dasar filsafat pendidikan diberbagai masyarakat yang menjadi dasar filsafat pendidikan. Karena dengan mengetahui sejarah maka kita dapat belajar lebih banyak bagaimana kita harus bersikap sehingga kita tidak akan mengulangi kesalahan yang sama dengan kesalahan yang pernah di lakukan oleh nenek moyang terdahulu sehingga menjadikan seseorang itu lebih baik.

Sejarah juga bisa membuat seseorang menghargai orang lain. Misalnya saat seorang pelajar Indonesia mempelajari sejarah kemerdekaan Indonesia, 
maka akan menjadikan pelajar itu lebih menghargai para pahlawan karena jerih payahnya memperjuangkan kemerdekaan. ${ }^{7}$

\section{Asas Sosial}

Pendidikan merupakan salah satu bentuk interaksi antar manusia. Aspekaspek sosial pendidikan dapat digambarkan sengan memandang ketergantungan antara individu yang satu dengan yang lainnya.

Dimensi-dimensi yang sering dibicarakan dalam sosial pendidikan antara lain adalah sebagai berikut :

a) Fungsi-fungsi sosial yang dimainkan oleh pendidikan yang berlaku di sekolah, misalnya pewarisan budaya dari generasi tua ke generasi muda.

b) Ciri-ciri budaya yang dominan dalam kawasan tertentu di sekolah. Misalnya istilah "pesantren" di Indonesia, sedangkan di Arab namanya "kuttab".

c) Faktor-faktor organisasi dari sistem birokrasi. Adanya sistem administrasi yang hirarkis dan berlaku pada tiap organisasi yang berlaku disekolah.

d) Sistem pendidikan. Tidak ada sistem pendidikan yang tetap dan statis, sistem pendidikan selalu berubah karena mengikuti perkembangan jaman. ${ }^{8}$

Asas yang memerhatikan penciptaan suasana sosial yang dapat membaangkitkan semangat kerja sama antara peserta didik dengan pendidik dan masyarakat sekitarnya dalam menerima pelajaran agar lebih berdaya guna dan berhasil guna. Pendidik dapat memfungsikan sumber-sumber fasilitas dari masyarakat untuk kepentingan pelajarannya dengan membawa peserta didik untuk karyawisata, survei, pengabdian masyarakat (service projet), dan perkemahan (school camping). Dalam hal ini Rasulullah SAW bersabda : "Sebaik-baik manusia adalah mereka yang paling banyak manfaatnya terhadap manusia lain." (alHadits). ${ }^{9}$

\footnotetext{
7 Hasan Langgulung. Asas-Asas Pendidikan Islam. Jakarta: Al-Husna. 1996. 16

8 Lihat Hasan Langgulung, 17

9 Abdul Mujib, Ilmu Pendidikan Islam. Jakarta: Kencana Prenada Media. 2006. 175
} 


\section{Asas Ekonomi}

Dalam bidang ekonomi, yang sangat relevan dengan pendidikan biasanya adalah hal-hal yang berkaitan dengan investmen dan hasilnya. Artinya, kalau modal yang ditanam sekian maka akan mengharapkan keuntungan dari hal itu. Negara - negara industri memerlukan waktu lebih banyak untuk belajar, ini artinya lebih banyak investasi dalam pendidikan. Sedangkan dinegara tertentu waktu belajar lebih sedikit dan tentunya budgetnya juga lebih sedikit. Hasil dari pendidikan tidak harus selalu bersifat uang, tetapi hal-hal yang tidak bersifat benda. Misalnya status, kesempatan, maupun penghargaan. ${ }^{10}$

\section{Asas politik dan administrasi}

Salah satu aspek politik yaitu ideologi. Ideologi inilah yang ingin diterapkan disuatu negara melalui pendidikan, tetapi pelaksanaanya harus mempertimbangkan aspek-aspek administratif supaya bisa berkembang dengan baik. Sebenarnya asas ini sangat berkaitan dengan sistem pendidikan. Karena jika sistem pendidikan berubah, maka administrasinya pun ikut berubah.

Faktor-faktor yang menyebabkan berkembangnya administrasi pendidikan antara lain:

a) Beralihnya status lembaga pendidikan. Misalnya dari pondok mengaji menjadi sekolah formal. Atau dari STAIN ke IAIN maupun ke UIN.

b) Perluasan pendidikan di daerah-daerah tertentu.

c) Perubahan dan perkembangan yang berlaku pada sifat-sifat pengajaran dan tujan pendidikan.

d) Mengggunakan metode perencanaan ilmiah bagi pertumbuhan ekonomi, sosial, dan budaya.

Ciri-ciri umum administrasi pendidikan adalah sebagai berikut :

a) Administrasi pendidikan meliputi semua kerja, usaha dan semua proses yang berlaku di suatu lembaga pendidikan.

${ }^{10}$ Lihat Hasan Langgulung, 16 
b) Administrasi pendidikan adalah usaha kolektif sekaligus usaha kerjasama.

c) Administrasi pendidikan bertujuan untuk mencapai pemuasan keinginan dan kebutuhan manusia.

d) Administrasi pendidikan adalah proses sosial.

e) Proses administratif adalah kerjasama, kemanusiaan dan sosial.

f) Administrasi pendidikan merupakan usaha teratur yang menghendaki ketepatan dalam organisasi dan koordinasi.

g) Kerja administrasi pendidikan adlah kerja kepemimpinan yang memerlukan wujudnya kepemimpinan yang bijaksana yang membimbing pekerjapekerja dan menjaga aktivitas-aktivitasnya. ${ }^{11}$

\section{Asas Psikologi}

Hubungan psikologi dengan pendidikan yaitu bagaimana budaya, keterampilan, dan nilai-nilai masyarakat dipelajari, dari generasi tua hingga generasi muda agara identitas masyarakat terpelihara. Dengan adanya psikologi maka pendidik akan tahu bagaimana sifat-sifat dan perilaku peserta didik sehingga mampu menyampaikan materi dengan baik dan disesuaikan dengan perkembangan peserta didik sehingga tujuan pendidikan akan tercapai. ${ }^{12}$

\section{Asas Motivasi}

Pendidik harus berusaha membangkitkan minat peserta didiknya sehingga seluruh perhatian mereka tertuju dan terpusat pada bahan pelajaran yang sedang disajikan. Asas motivasi dapat diupayakan melalui pengajaran dengan cara yang menarik sesuai dengan tingkat perkembangan peserta didik, mengadakan selingan yang sehat, menggunakan alat-alat perasa yang sesuai dengan sifat materi, menghindari pengaruh yang mengganggu konsentrasi peserta didik, mengadakan kompetesi sehat dengan memberikan hadiah hukuman yang bijaksana.

\footnotetext{
11 Lihat Hasan Langgulung, 181

12 Lihat Hasan Langgulung, 251
} 


\section{Asas Apersepsi}

Mengalami dalam proses belajar erarti menghayati suatu situasi aktual yang sekaligus menimbulkan respon-respon tertentu dari pihak peserta didik, sehingga memperoleh perubahan pola tingkah laku (pematangan dan kedewasaan) perubahan dalam perbendaharaan konsep-konsep (pengertian), dan kekayaan akan informasi. Apersepsi adalah gejala jiwa yang dialami jika kesan baru masuk ke dalam kesadaran seseorang yang berjalin dengan kesan-kesan lama yang sudah dimiliki disertai proses pengelolaan, sehingga menjadi kesan yang lebih luas. Asas apersepsi bertujuan menghubungkan bahan pelajaran yang akan diberikan dengan apa yang telah dikenal oleh peserta didik.

\section{Asas Korelasi}

Peristiwa belajar mengajar adalah menyeluruh mencakup berbagai dimensi yang kompleks dan saling berhubungan. Itulah sebabnya dalam setiap pengajaran, pendidik hendaknya menghubungkan suatu bahan pelajaran dengan bahan pelajaran lainnya, sehingga membentuk mata rantai yang erat. Asas korelasi akan menimbulkan asosiasi dan apersepsi dalam kesadaran sekaligus membangkitkan minat peserta didik terhadap mata pelajaran. Seperti yang terdapat dalam firman Allah SWT berikut yang menganjurkan untuk mengorelasikan sesuatu pada sesuatu yang lain : "Maka tidaklah mereka bepergian di muka bumi lalu melihat bagimana kesudahan orang-orang sebelum mereka, dan sesungguhnya kampung akhirat lebih baik bagi orang-orang yang bertakwa, maka tidaklah kami memikirkannya”. (QS. Yusuf: 109).

\section{Asas Evaluasi}

Asas yang memerhatikan hasil dari penilaian terhadap kemampuan yang dimiliki peserta didik sebagai feedback pendidik dalam memperbaiki cara mengajar. Asas evaluasi tidak hanya diperuntukkan bagi peserta didik, tetapi 
jugabagi pendidik yaitu sejauh mana keberhasilannya dalam menunaikan tugasnya. $^{13}$

\section{Asas Globalisasi}

Asas sebagai akibat pengaruh psikologi totalitas, yaitu peserta didik bereaksi terhadapingkungan secara keseluruhan, tidak hanya secara intelektual, tetapi juga secara fisik, soosial, dan sebagainya.

\section{Asas Pusat-pusat Minat}

Asas yang memerhatikan kecenderungan jiwa yang tetap kejurusan suatu hal yang berharga bagi seseorang. Sesuatu berharga apabila sesuai dengan kebutuhan. Pelaksaan asas pusat-pusat minat dala, Islam dengan ruang lingkupnya terdiri atas bahan hubungan dengan Tuhan, manusia dengan sesama manusia dan manusia terhadap alam semesta.

\section{Asas Keteladanan}

Pada fase-fase tertentu, peserta didik memiliki kecenderungan belajar lewat peniruan terhadap kebiasaan dan tingkah laku orang disekitarnya., khususnya pada pendidik yang utama (orang tua).

\section{PENUTUP}

1. Asas pendidikan Islam adalah asas perkembangan dan pertumbuhan dalam perikehidupan yang berkeseimbangan antara kehidupan duniawiah dan ukhrawiah, jasmaniah dan rohaniah atau antara kehidupan materiil dan mental spiritual.

2. Macam-macam asas pokok pendidikan, antara lain asas tut wuri handayani, asas belajar sepanjang hayat, serta asas kemandirian belajar.

3. Macam-macam asas-asas pendidikan diantaranya, asas historis, asas sosial, asas ekonomi, asas politik dan administrasi, asas psikologi, asas motivasi, asas

\footnotetext{
13 Lihat Abdul Mujib, 176
} 
apersepsi, asaskorelasi, asas evaluasi, asas globalisasi, asas pusat-pusat minat serta asas keteladanan.

\section{DAF TAR PUSTAKA}

Aziz, A., \& Saihu, S. (2019). Interpretasi Humanistik Kebahasaan: Upaya Kontekstualisasi Kaidah Bahasa Arab. Arabiyatuna: Jurnal Bahasa Arab, 3(2), 299-214

Langgulung, Hasan. 1996. Asas-Asas Pendidikan Islam. Jakarta: Al-Husna.

Mubin, F. (2019). TAFSIR EMANSIPATORIS: PEMBUMIAN METODOLOGI TAFSIR PEMBEBASAN. Mumtaz: Jurnal Studi AlQuran dan Keislaman, 3(1), 131-151.

Mubin, F. KEADILAN DALAM GENDER: KAJIAN KEPEMIMPINAN WANITA DALAM ISLAM1,

Mubin, F. MODEL-MODEL PEMBELAJARAN BERBASIS MADRASAH DAN KEGIATAN LAIN YANG DIPERLUKAN DI DALAMNYA (FAKTOR PENDUKUNGNYA).

Mujib, Abdul. 2006. Ilmu Pendidikan Islam. Jakarta: Kencana Prenada Media.

Nata, Abudin. 2012. Ilmu Pendidikan Islam. Jakarta : Kencana Prenada Media Grop.

Ronaldo, R., Zulfikar, A., Saihu, Ismail, \& Wekke, I. S. (2020). International relations of the asia pacific in the age of trump. Journal of Environmental Treatment Techniques, 8(1), 244-246.

Şahin, C. RELIGIA.

Saihu, Aziz, A., Mubin, F., \& Sarnoto, A. Z. (2020). Design of islamic education based on local wisdom (An analysis of social learning theories in forming character through ngejot tradition in bali). International Journal of Advanced Science and Technology, 29(6), 1278-1293.

Saihu, M. (2019). Urgensi 'Urf dalam Tradisi Male dan Relevansinya dalam Dakwah Islam di Jembrana-Bali. Jurnal Bimas Islam, 12(1), 173-201.

Saihu, M. (2019). Merawat Pluralisme Merawat Indonesia (Potret Pendidikan Pluralisme Agama Di Jembrana-Bali). Deepublish.

Saihu, M. M., \& Aziz, A. (2020). Implementasi Metode Pendidikan Pluralisme Dalam Mata Pelajaran Pendidikan Agama Islam. Belajea; Jurnal Pendidikan Islam, 5(1), 131-150.

Saihu, S. (2019). IMPLEMENTASI MANAJEMEN BALANCED SCORECARD DI PONDOK PESANTREN JAM'IYYAH ISLAMIYYAH TANGERANG SELATAN. Mumtaz: Jurnal Studi AlQuran dan Keislaman, 3(1), 1-22. 
Saihu, S. (2019). KOMUNIKASI PENDIDIK TERHADAP ANAK BERKEBUTUHAN KHUSUS DI SEKOLAH KHUSUS ASY-SYIFA LARANGAN. Andragogi: Jurnal Pendidikan Islam dan Manajemen Pendidikan Islam, 1(3), 418-440.

Saihu, S. (2019). KONSEP MANUSIA DAN IMPLEMENTASINYA DALAM PERUMUSAN TUJUAN PENDIDIKAN ISLAM MENURUT MURTADHA MUTHAHHARI. Andragogi: Jurnal Pendidikan Islam dan Manajemen Pendidikan Islam, 1(2), 197-217.

Saihu, S. (2019). PENDIDIKAN KARAKTER BERBASIS KEARIFAN LOKAL (STUDI DI JEMBRANA BALI). Edukasi Islami: Jurnal Pendidikan Islam, 8(01), 69-90.

Saihu, S. (2019). Pendidikan Pluralisme Agama: Kajian tentang Integrasi Budaya dan Agama dalam Menyelesaikan Konflik Sosial Kontemporer. Jurnal Indo-Islamika, 9(1), 67-90,

Saihu, S. (2019). RINTISAN PERADABAN PROFETIK UMAT MANUSIA MELALUI PERISTIWA TURUNNYA ADAM AS KEDUNIA. Mumtaz: Jurnal Studi Al-Quran dan Keislaman, 3(2), 268279 ,

Saihu, S. (2020). ETIKA MENUNTUT ILMU MENURUT KITAB TA'LIM MUTA'ALIM. Al Amin: Jurnal Kajian Ilmu dan Budaya Islam, 3(1), 99-112.

Saihu, S. (2020). KONSEP PEMBAHARUAN PENDIDIKAN ISLAM MENURUT FAZLURRAHMAN. Andragogi: Jurnal Pendidikan Islam dan Manajemen Pendidikan Islam, 2(1), 82-95.

Saihu, S. (2020). Pendidikan sosial yang terkandung dalam Surat At-Taubah Ayat 71-72. Edukasi Islami: Jurnal Pendidikan Islam, 9(01), 127-148.

Saihu, S. (2020). The Effect of Using Talking Stick Learning Model on Student Learning Outcomes in Islamic Primary School of Jamiatul Khair, Ciledug Tangerang. Tarbawi: Jurnal Keilmuan Manajemen Pendidikan, 6(01), 61-68.

Saihu, S., \& Mailana, A. (2019). Teori pendidikan behavioristik pembentukan karakter masyarakat muslim dalam tradisi Ngejot di Bali. Ta'dibuna: Jurnal Pendidikan Islam, 8(2), 163-176.

Saihu, S., \& Marsiti, M. (2019). PENDIDIKAN KARAKTER DALAM UPAYA MENANGKAL RADIKALISME DI SMA NEGERI 3 KOTA DEPOK, JAWA BARAT. Andragogi: Jurnal Pendidikan Islam dan Manajemen Pendidikan Islam, 1(1), 23-54.

Saihu, S., \& Rohman, B. (2019). PEMBENTUKAN KARAKTER MELALUI MODEL PENDIDIKAN TRANSFROMATIFE LEARNING PADA SANTRI DI PONDOK PESANTREN NURUL IKHLAS BALI. Edukasi Islami: Jurnal Pendidikan Islam, 8(02), 435452. 
Saihu, S., \& Taufik, T. (2019). PERLINDUNGAN HUKUM BAGI GURU. Al Amin: Jurnal Kajian Ilmu dan Budaya Islam, 2(2), 105-116. Uhbiyati, Nur. 1999. Ilmu Pendidikan Islam. Bandung: CV Pustaka Setia.

W.J.S, Purwadarminta. 2001. Kamus umum Bahasa Indonesia, Jakarta: Balai Pustaka. 